\title{
Fraud of Financial Statements in Diamond Theory's Perspective: Empirical Study of Transportation Sub Sector Companies in The Indonesia Stock Exchange
}

\author{
Amelia Oktrivina Siregar ${ }^{1}$, M. Adam Prayoga ${ }^{2}$, Eka Sudarmaji ${ }^{3}$ \\ Fakultas Ekonomi \& Bisnis, Universitas Pancasila, Jakarta, Indonesia ${ }^{1}$ \\ Fakultas Ekonomi \& Bisnis, Universitas Pancasila, Jakarta, Indonesia ${ }^{2}$ \\ Fakultas Ekonomi \& Bisnis, Universitas Pancasila, Jakarta, Indonesia ${ }^{3}$
}

\begin{abstract}
This study aims to obtain empirical evidence in detecting fraudulent financial statements from the perspective of 'fraud diamond theory'. The proxy variables used in this study are the influence of pressure, opportunity, rationalization, and ability. This study uses a sample of transportation sub-sector companies listed on the Indonesia Stock Exchange (IDX) in the period of 2015-2017. This research is expected to contribute to the development of accounting science, especially in the field of forensic accounting regarding factors that can affect companies to conduct fraudulent financial statements by implementing indicators of diamond fraud. Hypothesis testing used multiple linear regression analysis with the help of application eviews software, to help process research data in the form of panel data. The results of this study indicate that pressure, opportunity, rationalization, and ability together were not significantly influence the tendency of fraudulent financial statements.
\end{abstract}

Keyword. theory of diamond fraud; financial fraud; transportation; IDX report

Article history. Received January, 2019. Revised March, 2019. Accepted June, 2019

Corresponding author. Email: ameliaoktrivina@univpancasila.ac.id

How to cite article. Siregar, A. O., Prayoga, M. A., Sudarmaji, E., Ekonomi, F., \& Pancasila, U. (2019). Fraud of Financial Statements in Diamond Theory's Perspective: Empirical Study of Transportation Sub Sector Companies in The Indonesia Stock Exchange. The International Journal of Business Review (The Jobs Review), 2(1), 63-74. https://doi.org/https://doi.org/10.17509/tjr.v2i1.23142

\section{INTRODUCTION}

The presentation of financial statements at a glance can seem simple, but the importance of the information content makes managers motivated to improve company performance, so that the company's existence is maintained. Sometimes management is willing to commit fraud (fraud) so that the information in the financial statements looks good. Bologna and Lindquist (1995) define fraud as intentional fraud generally explained as lying, plagiarism, and theft. In addition, the Association of Certified Fraud Examinations (ACFE) categorizes fraud in three groups: corruption (corruption), misuse of assets (asset misappropriation), and fraudulent statements (fraudulent statements). Fraud indiscriminately, quoted from wartaekonomi.co.id, "Multinational companies also experience fraud.

Financial report fraud also occurred in Indonesia. In going public, overstatements were found for the year ended December 31, 2001. Fraudulent financial statements even occurred in state-owned enterprises (SOE) companies. One of the phenomena of financial statement fraud in Indonesia is the case of a state-owned company engaged in the transportation sector, where it is suspected the manipulated financial statement data occurred, the SOE company recorded it a profit of IDR 6.9 billion, even though in fact suffered a loss of IDR 63 billion.In this financial statement fraud issue, the role of the auditor profession is needed to detect as 
AMELIA OKTRIVINA SIREGAR ${ }^{1}$, M. ADAM PRAYOGA ${ }^{2}$ EKA SUDARMAJI $/$ Fraud of Financial Statements in Diamond Theory's Perspective: Empirical Study of Transportation Sub Sector Companies in

The Indonesia Stock Exchange

early as possible fraud, so as to prevent fraud and the possibility of prolonged scandal. Auditors must be able to consider the possibility of fraud from various perspectives, one of the theories that is often used to assess fraud is the fraud triangle theory (fraud triangle) that was coined by Cressey (1953). Cressey (1953) revealed that financial reporting fraud occurs always followed by three conditions, namely pressure (opportunity), opportunity (opportunity), and rationalization (rationalization). Over time, there will continue to be developments in the theory of fraud triangle put forward by Cressey. The first development put forward by Wolfe and Hermanson in 2004 with fraud diamond theory, in this theory adds a qualitative element that is believed to have a significant influence on fraud, namely capability. Therefore, this research was conducted on the background of concerns about cases of fraud in financial statements, especially in companies engaged in the transportation sector, which tend to be quite difficult to disclose the factors that influence it. Until now, there is still little research done to explore this case, especially by using the concept of fraud diamond.

This research is expected to be able to find out whether pressure, opportunity, rationalization, and capability have an effect on financial statement fraud. This research can also contribute to the development of accounting science, especially in the field of forensic accounting regarding the factors that can influence companies to commit financial statement fraud by applying the indicator elements of fraud diamonds. The results of the research can be used as a reference for future research improvement or to add insight. As an academic and research improvement on the factors that influence the financial statement fraud.

Agency theory is a theory that underlies the company's business practices used so far. This theory explains the relationship between company owners (shareholders) and management. Jensen and Meckling (1976) in Melia (2016), state that agency theory describes shareholders as principals and management as agents. Companies as agents face various pressures to determine ways for company performance to always improve with the expectation that by increasing performance the principal will give an appreciation (rationalization). The gate to fraud will be more open if management has the opportunity (Opportunity) and ability (Capability) to increase profits. Earnings management actions taken by management due to conflict of interest and asymmetric information with the owner is one form of financial statement fraud. Based on this, there is an agency problem between the owner (principal) and management (agent) which results in fraudulent financial statements that are misleading and detrimental.

Fraud is literally interpreted as cheating, this term is generally used to drop or judge individuals or groups who commit fraud or actions against the law for personal or group interests that cause harm to other parties when they do or in the future.

In the accounting literature, fraud is called white-collar crime, abuse of trust, embezzlement, and deviation. The Indonesian Accounting Association (IAI, 2012) states the definition of fraud (fraud) is "Every accounting action as: (a) Misstatement arising from fraud in financial reporting that is misstatement or intentional disappearance of the amount or disclosure in the financial statements to fool the users of the report financial, (b) Misstatements arising from improper treatment of assets (often referred to as misuse or embezzlement) relating to theft of company assets resulting in financial statements not presented in accordance with generally accepted accounting principles in Indonesia ".

From the Uniform Occupational Fraud Classification System chart, The ACFE (Association of certified Fraud Examiner, 2000) or often called fraud tree is divided into three actions, namely the first Asset Misappropriation, this deviation includes misuse, embezzlement or theft of company assets / assets. or other parties, which consist of cash fraud and misuse of 
inventory and other assets, second is fraudulent Financial Statements (Fraudulent Statement), fraudulent financial statements include actions taken by officials or government agencies to cover the actual financial condition by conducting financial engineering (financial engineering) or beautifying financial statements (window dressing) by presenting financial statements that are better than the truth (over statement) and worse than the truth (under statement). Examples are recording fictitious income, minimizing reported expenses, or inflating assets, and finally corruption, corruption including abuse of authority or conflict of interest, bribery, illegal acceptance (illegal gratuities). This type of fraud is the most difficult to detect because it involves collaboration with other parties or collusion, this type of fraud can often not be detected because the parties that cooperate enjoy the benefits.

\section{Fraud Triangle Theory}

One of the basic concepts of fraud prevention and detection is the fraud triangle. This concept is also called Cressey's Theory because indeed this term emerged because of research conducted by Donald R. Cressey in 1953. Cressey's research was published under the title Other's People Money: A Study in the Social Psychology of Embezzelent. Cressey's research in general explains the reasons why people commit fraud. There are three elements of the Fraud triangle, among others: Opportunity (opportunity), Rationalization (rationalization), and Pressure (pressure). Pressure is a condition that drives someone to commit fraud. Pressure can cover everything, including financial and non-financial matters. With the condition depressed due to pressure arising from the company's internal and external parties the company can trigger fraud.

SAS No. 99 states that financial stability is a condition that illustrates the company's financial condition in a stable condition. It is possible for companies to manipulate profits when financial stability or profitability is threatened by economic conditions. Skousen, et al., (2008) use Gross profit margin (GPM), sales changes (SCHANGE), asset change (ACHANGE), negative cash flow (CATA), and sales to account receivable (SALAR) ratio. Asset change (ACHANGE) illustrates the company's growth before the company commits fraud. The higher the ACHANGE, the higher the growth that must be maintained. SAS No. 99 states that excessive pressure for management to meet the requirements or expectations of third parties can lead to fraud. Leverage (LEV) is one indicator that can illustrate the pressure coming from outside the company. The greater the leverage, the greater the funds coming from loans. As a result, many things must be obeyed so as not to violate the debt covenant.

Excessive pressure on management to achieve financial targets set by directors or management. The company may manipulate earnings to meet estimates or benchmarks of analysis such as previous year's earnings. Return on assets (ROA) is a profitability ratio that is used to measure the effectiveness of a company in generating profits by utilizing its assets (Skousen et al., 2008). Higher ROA accompanied by an increase in ROA from period to period shows the company's performance is getting better, if ROA has decreased every year will trigger fraud.

Fraud can be done if there is an opportunity or opportunity to do so. That opportunity can be taken if the fraud that is done has a small risk to be known and detected. In accordance with SAS No. 99 there are two factors:

Associated with the emergence of risk for companies involved in the industry involving significant estimates and considerations far greater. Inventory valuation can pose a greater risk of misstatement for companies whose inventory is spread in many locations. The risk of inventory misstatement will increase if the inventory becomes obsolete. Skousen, et al., (2008) include RECEIVABLE and INVENTORY as a proxy for the nature of the industry. 
AMELIA OKTRIVINA SIREGAR ${ }^{1}$, M. ADAM PRAYOGA ${ }^{2}$ EKA SUDARMAJI $/$ Fraud of Financial Statements in Diamond Theory's Perspective: Empirical Study of Transportation Sub Sector Companies in

The Indonesia Stock Exchange

The greater RECEIVABLE and INVENTORY, the greater the account that can be used to manipulate. As a result, fraud is more likely to occur.

A condition where the company does not have an effective supervisory unit to monitor company performance. Dechow et al., In Skousen et al., (2008) stated that fraud companies have fewer independent members in the board of directors compared to non-fraud companies. BDOUT describes the number of independents in the board. The greater the BDOUT, the more independent members there are, the more stringent internal controls the opportunity to commit fraud will decrease.

Almost all fraud is motivated by Rationalization (Rationalization). Rationalization can also be called justification. Rationalization makes someone who initially did not want to commit fraud in the end did it. Rationalization is a personal reason (because there are other factors) that can justify an action even though the action was actually wrong. Frauders usually look for rational justifications to justify their actions, making them difficult to detect. In SAS No. 99 rationalization is divided into two factors, namely rationalization and auditor change. Change of auditors is carried out so that the risk of fraud is detected to fall. This is illustrated by the AUDCHANGE variable. Repeated attempts by management to justify the use of inappropriate accounting policies can cause fraud. This is illustrated by the variable rationalization. The use of excessive discretionary accruals can make the company get a fair opinion with an exception.

\section{Diamond Fraud Theory}

Fraud diamond is a new theory that explains the phenomenon of fraud proposed by Wolfe and Hermanson (2004). Fraud diamond is a form of development and refinement of the Fraud triangle theory by Cressey (1953). Fraud diamond is a theory that can be used to improve fraud prevention and detection by considering Pressure, Opportunity, and Rationalization, by adding a qualitative element that is believed to have a significant influence on fraud, namely Capability.

Capability As a fourth element, capability is often referred to as individual ability. The individual must have the ability to recognize opportunities as opportunities and take advantage of them (Fraud Auditing \& Investigation, p. 47, 2013). Wolfe and Hermanson (2004) examined capability as one of the fraud risk factors behind the occurrence of fraud and concluded that changes in directors could indicate fraud. Changes in directors are not always good for the company. Changes in directors can be an attempt by the company to improve the performance of the previous directors by changing the composition of the directors or recruiting new directors who are considered more competent than the previous directors. While on the other hand, the change of directors may be an attempt by the company to get rid of directors who are considered to know fraud.

In Statement on Auditing Standards (SAS) No.99 (AU 316), entitled Consideration of Fraud in a Financial Statement Audit, issued by the Auditing Standard Board (ASB) under the auspices of the American Institute of Public Accountants (AICPA) in November 2002, There are two types of misstatements that are relevant to financial statement audits and auditor's judgment regarding fraud. There are three main groups that have the opportunity to do this Fraud, including: Senior Management, Mid and Lower Level, and Employees Organized Criminals Senior managers (CEO, CFO, etc.) and business owners may cook the books for several reasons including: To Conceal True Business Performance, done by overserving (overstate) and under-serving (understate) the actual results, To Preserve Personal Status / Control, Senior managers who may have high egos do not want to acknowledge the failure of the strategies they have implemented that cause company performance to be bad 
and To Maintains Personal Income / Wealth, Increase income or anything that can improve individual welfare, for example: salary, bonuses, stocks, and stock options.

The Committee of Sponsoring Organizations (COSO) of the Treadway Commissions in Tuanakotta (2010) conducted a study of the Financial Statement Fraud and developed a taxonomy that might occur in all businesses. COSO identifies the Fraud mode in several areas, including: 1) Recognizing undue revenue, 2) Over serving assets (other than trade receivables related to fraudulent recognition of income), 3) Underpayment / liabilities, 4) Misuse of assets , 5) Improper disclosure and 6) Other possible techniques.

Of the various possibilities for the occurrence of Fraud Financial Statements, the more frequent reporting of earnings is the most common occurrence first, through Overstating Revenues: Sham Sales, Premature Revenue Recognition, Recognition of Conditional Sales, Abuse of Cut-off Date of Sales and Misstatement of the Percentage of Completion. The second is through Overstating Sales using Inventories, Accounts Receivable and Property, Plan and Equipment.

\section{METHOD}

This study determines whether there is an influence of fraud indicators in identifying the occurrence of fraudulent financial statements in order to be prevented so that fraud cannot occur. In this study, the variables of fraud indicators are taken based on the theory of fraud triangle and diamond. However, fraud indicators cannot be just examined so they require variable proxies. This study uses seven independent proxy variables. This is due to adjustments to the company's financial statement data available for research.

This study uses quantitative analysis methods as the method of analysis. The dependent variable in this study is the tendency of financial statement fraud by using a fraud score model. The variable component of the f-score includes two things that can be seen in the financial statements, namely accrual quality (proxy quality) which is proxied by RSST (Rechange Asset) and financial performance (financial performance).

F- Score $=$ Accrual Quality + Financial Performance

Accrual quality is obtained from the following calculation:

Accrual Quality $=\frac{\Delta \mathrm{WC}+\Delta \mathrm{NCO}+\Delta \mathrm{FIN}}{\text { Average Total Asset }}$

Where:

$\mathrm{WC}=$ Working Capital, (Current Assets - Current Liability)

$\mathrm{NCO}=$ Non - current operating accrual, $($ Total Assets - Current Assets - Investment $)-$ Liabilities - Current Liabilities - Long Term Debt)

FIN = Financial Accrual, FIN = Total Investment - Total Liabilities

ATS = Average Total Assets, $($ Beginning Total Assets + End Total Assets $) / 2$

Financial performance is obtained from calculations illustrated by the formula:

Financial Performance $=$ change in receivable + change in inventories + change in cash sales + change in equity

Where:

Changes in receivable $=\Delta$ Receivable / Average Total Assets

Changes in inventory $=\Delta$ Inventory/Average Total Assets

Changes in cash sales $=[(\Delta$ Sales / sales $(t)-(\Delta$ Receivable / receivable $(t))]$

Changes in equity $\quad=[($ Earnings $(t) /$ Average Total Assets $(t))-($ Equity $(t-1) /$ Average total Assets $(t-1))]$ 
AMELIA OKTRIVINA SIREGAR ${ }^{1}$, M. ADAM PRAYOGA ${ }^{2}$,EKA SUDARMAJI ${ }^{3} /$ Fraud of Financial Statements in Diamond Theory's Perspective: Empirical Study of Transportation Sub Sector Companies in

The Indonesia Stock Exchange

The independent variable in this study is a component contained in the diamond fraud factor, namely pressure, opportunity, rationalization and capability, referring to the research conducted by Wolfe and Hermanson (2004). The four components cannot be directly measured directly, therefore a proxy is needed in the development of measuring these variables. The independent variables and measurements used are as follows: 1) Pressure (SAS) No. 99 states that pressure can come from financial stability (Assets Change), external pressure (leverage), and financial targets (ROA). 2) Opportunity, SAS No. 99 states that opportunities can originate from the nature of the industry the company is in. (Calculated) is calculated by the formula used by Skousen (2009) and ineffectiveness of supervision, proxied by ineffectiveness of supervision on the ratio of the number of independent directors to the formula used by Sihombing (2014), 3) Rationalization (Rationalization), proxied by changes in external auditors according to (Summers and Sweeney, 1998; Lou and Wang, 2009) and 4) Capability, according to Wolfe and Hermanson (2004), capability variable is proxied by changes in directors.

Based on this framework, a provisional formulation or conjecture can be drawn as the following hypothesis:

H1: Pressure influences the tendency of report fraud finance

$\mathrm{H} 2$ : Opportunity influences the tendency of report fraud finance

H3: Rationalization affects the tendency of fraud financial statements

H4: Capability influences the tendency of report fraud finance

H5: Pressure, Opportunity, Rationalization and Capability influence simultaneously against the tendency of financial statement fraud.

This study uses quantitative data types from the concept of diamond fraud to the tendency of financial statement fraud. The data used in this study are secondary data obtained from the IDX (Indonesian Stock Exchange) in 2015 - 2017 and books, journals, previous research, and internet sites. The population in this study are all transportation sub-sector companies listed on the Indonesia Stock Exchange during the 2015-2017 period. The sampling technique is done by purposive sampling. The criteria in the sample selection in this study are as follows: 1) Transportation sub-sector companies that have gone public or listed on the Indonesia Stock Exchange (IDX) during the period 2015 - 2017, 2) Companies that publish complete financial statements and annual reports on the company's website or the IDX website for the period 2015 - 2017 expressed in rupiah (Rp) and 3) Companies that have complete information for measuring related variables.

Table 1. Sample Selection Criteria

\begin{tabular}{clc}
\hline No. & \multicolumn{1}{c}{ Sample Criteria } & Amount \\
\hline 1 & $\begin{array}{l}\text { Transportation sub sector companies listed on the Indonesia } \\
\text { Stock Exchange (IDX) for the 2015-2017 period } \\
2\end{array}$ & 35 \\
& $\begin{array}{l}\text { Transportation sub sector companies that do not have } \\
\text { complete data information needed by researchers in ICMD } \\
\text { during the 2015-2017 period }\end{array}$ & \\
3 & $\begin{array}{l}\text { Companies that do not publish annual reports in 2016 } \\
4\end{array}$ & Companies that do not publish annual reports in 2015 \\
5 & Number of Samples & $(6)$ \\
\hline
\end{tabular}


Based on the criteria used in having a sample, there are nineteen transportation subsector companies that can be sampled for this study. This analysis uses quantitative analysis by quantifying research data so as to produce the information needed in the analysis. Data analysis techniques use multiple linear regression methods to see the tendency of companies that commit fraud. Multiple linear regression analysis is used to model and investigate the effect of one or several independent variables (Independent Variables) on one response variable (Dependent variable). The multiple linear regression equation used is as follows:

\section{$Y=\alpha+\beta_{1}$ ROA $+\beta_{2}$ ACHANGE $+\beta_{3}$ LEVERAGE $+\beta_{4}$ BDOUT $+\beta_{5}$ RECEIVABLE $+\beta_{6}$ AUDCHANGE $+\beta_{7}$ DCHANGE $+e$}

Where:

$\mathrm{Y}=$ Trend of Fraudulent Financial Statements (F-SCORE)

$\alpha=$ Constant

$\beta 1=$ Regression coefficient for financial targets (ROA)

$\beta 2=$ Regression coefficient for financial stability (ACHANGE)

$\beta 3$ = Regression coefficient for external pressure (LEVERAGE)

$\beta 4=$ Regression coefficient for ineffective supervision (BDOUT)

$\beta 5=$ Regression coefficient for industrial properties (RECEIVABLE)

$\beta 6=$ Regression coefficient for auditor change (AUDCHANGE)

$\beta 7=$ Regression coefficient for directors change (DCHANGE)

$\mathrm{e}=$ Standard error

Data processing uses Eviews software due to this type of data includes panel data. The panel data regression analysis is a regression model that combines time series data with cross section data. The regression estimation method uses panel data can be done through three approaches, including: 1) Common Effect Model, the model assumes that corporate data behavior is the same in various periods of time. This common effect model can use the Ordinary Least Square (OLS) approach or the least squares technique to estimate the panel data model, 2) Fixed Effect Model, this model assumes that differences between individuals can be accommodated from intercept differences, but have the same slope (fixed) between companies and between times. To estimate the fixed effect model panel data, a dummy variable technique or often called the least square dummy variable (LSDV) technique is used to capture intercept differences between companies and 3) Random Effect Model, this random effect model estimates the panel data in which variables disorders may be interconnected between time and between individuals. In this model the difference in intercept uses the error terms of each company.

To choose the most appropriate model for managing panel data, there are a number of tests that can be performed, including: 1) Chow test is used to determine the fixed effect or common effect model that is most appropriate for estimating panel data, 2) Hausman test is used for testing statistics to choose whether the fixed effect or random effect model is best used in estimating panel data. Meanwhile this classic assumption test is intended to find out and test the feasibility of the regression model to ensure that there is no multicollinearity, autocorrelation and heteroscedasticity in the regression model and to ensure that the data produced are normally distributed. The classic assumption testing used is the Normality Test, the Multicollinearity Test, the Autocorrelation Test and the Heteroscedasticity Test.

\section{RESULTS AND DISCUSSION}

Total transportation sub-sector companies registered and have complete data to study are 19 companies, so the total data in three years of observation is 57 data ( 19 companies x 3 years). Then the Fraud Score is calculated for each of these companies. The fraud score calculation results are then adjusted to the criteria for the fraud score indicator. Sukrisnadi (2010) in his 
AMELIA OKTRIVINA SIREGAR ${ }^{1}$, M. ADAM PRAYOGA ${ }^{2}$, EKA SUDARMAJI $/$ Fraud of Financial Statements in Diamond Theory's Perspective: Empirical Study of Transportation Sub Sector Companies in The Indonesia Stock Exchange

research mentioned a benchmark indicator of the F-Score value to measure the level of risk of financial statement misstatement, namely:

Table 2. Indikator Fraud Score

\begin{tabular}{lll}
\hline Average Value & $\mathrm{F}-$ Score & categories \\
\hline $\mathrm{F}-$ Score $>2,45$ & & High risk \\
$\mathrm{F}-$ Score $>1,85$ & & Substantial risk \\
$\mathrm{F}-$ Score $>1$ & Risk above normal \\
$\mathrm{F}-$ Score $<1$ & Low risk \\
\hline
\end{tabular}

Based on the calculation of the fraud score model, it can be concluded that of the 19 transportation sub-sector companies analyzed, the companies that indicated a tendency to fraudulent financial statements were 11 companies, the fraud that entered and became the sample of this study was fraud in the high to low category.

Based on the results of fraud-score testing, Thus, the total amount of data in this study can be concluded as follows:

Table 3. Sample Selection List

\begin{tabular}{clc}
\hline No. & \multicolumn{1}{c}{ Remarks } & Amount \\
\hline 1 & $\begin{array}{l}\text { Transportation sub sector companies that have gone public } \\
\text { or are listed on the Indonesia Stock Exchange in 2015 - 2017 }\end{array}$ & 0 \\
2 & $\begin{array}{l}\text { Companies that do not publish annual reports and financial } \\
\text { reports for 2015 - 2017 }\end{array}$ & -8 \\
3 & $\begin{array}{l}\text { Companies that are not indicated to manipulate (fraud) at } \\
\text { least 1 time during 2015 -2017 using a fraud score (F-Score) } \\
\text { Total }\end{array}$ & 11 \\
\hline
\end{tabular}

To choose the best regression model among Common Effects, Fixed Effects, and Random Effects, several Chow Tests were conducted. Based on the chow test results obtained Chi-square probability value of 0,000 . This means that the value of $0,000<0.05$ then $\mathrm{H} 0$ is rejected. Thus, the results of the chow test can be concluded that the right model for panel data regression is the fixed effect model. To compare which model is the best between fixed effects or random effects, the Hausman Test is used.

Based on the Hausman test results obtained probability value of 0,000 . This means that the value of $0,000<0.05$ then $\mathrm{H} 1$ is accepted. Thus, the Hausman test results can be concluded that the right model for panel data regression is a fixed effect model. By getting the Hausman test with the $\mathrm{H} 1$ results accepted, by establishing fixed effect as the most appropriate panel data estimation model, there is no need for a third test, the Lagrange Multiplier test. After testing the panel data regression model using the Chow test and Hausman test, it can be concluded that the panel data regression model that is most appropriate in this study is the fixed effect model.

Meanwhile based on the Classic Assumption Test, the probability value of Jarque Bera is 0.474545 . This shows that the residual data is normally distributed, because the probability value of Jarque Bera is $0.474545>\alpha(0.05)$. When using histogram analysis, the data is also classified as normal distribution, because it looks symmetrical and if a line is formed at each point it will form a bell pattern. In the Multicollinearity Test Results the correlation coefficient test results indicate that all independent variables have a correlation coefficient 
value $<0.80$. Thus, it can be concluded that the test data does not have multicollinearity or there is no correlation between each independent variable in the regression model. For the Autocorrelation Test, this is done by using the Durbin Watson test (DW test).

Based on Durbin Watson's value of 2.887306. To obtain the magnitude of dL and dU can be seen in the Durbin Watson table, using a significant value $\alpha=5 \%$, independent variable $7(\mathrm{k}=7)$, and the amount of data $33(\mathrm{n}=33)$, thus the $\mathrm{dL}$ results of 1.06065 and $\mathrm{dU}$ of 1.89986.The conclusion of the autocorrelation test as in table 4.9 is $\mathrm{dU}<\mathrm{dW}<4-\mathrm{dU}$, then the statistical $\mathrm{dW}$ value $=2.887306$ is in the area of no positive or negative autocorrelation. As the analysis is $1.89986<2.887306<(4-1.89986)$. Therefore, it can be concluded that there is no autocorrelation problem. In the Heteroscedasticity Test, it can be concluded that each independent variable is free from heteroscedasticity. This can be proven from the significance value of each independent variable that produces a significant value> 0.05 . Based on multiple regression analysis obtained:

$Y($ fraud score $)=-129,4434+8,461334$ ROA + (-1,327686) ACHANGE + $(-2,457008)$ LEVERAGE + $(-10.29456)$ RECEIVABLE + 299,3343 BDOUT + (-5,072450) AUDCHANGE + 1,724305 DCHANGE

The constant value is -129.44434 , this means that if ROA, ACHANGE, LEVERAGE, RECEIVABLE, BDOUT, AUDCHANGE, and zero DCHANGE (0), the fraud score (y) is -129.44434 . The test results above show that the $\mathrm{F}$ value of the F-statistic probability is 0,000 . So that the probability value of F-statistic 0,000 <significant (0.05), thus it can be concluded that the independent variables in the form of pressure, opportunity, rationalization and capability together (simultaneously) affect the dependent variable that is the tendency of financial statement fraud.

Determination Coefficient Test (Adjusted R-squared), Test the coefficient of determination is essentially measuring how much the ability of the model in explaining the dependent variable (Nathaniel, 2008). The results of the coefficient of determination test can be seen in table 4.14 adjusted R-squared of $97.7556 \%$. This shows that the influence of pressure variables (proxied by ROA, ACHANGE and LEVERAGE), opportunity variables (proxied by RECEIVABLE and BDOUT), rationalization variable (proxied with AUDCHANGE) and capability variable (proxied with DCHANGE) to the tendency of financial statement fraud which can be explained by this equation model is $97.8 \%$ and the remaining $2.2 \%$ is explained by variables outside the model. Based on the test results that have been done by the author, it can be concluded the test results from the discussion of the hypothesis that can be seen in the table 4 as follows:

Table 4. Conclusion of Hypothesis Testing Results

\begin{tabular}{|c|c|c|c|c|}
\hline Variable & Hypothesis & Dimension & Result & Interpretation \\
\hline \multirow[t]{3}{*}{ Pressure } & H1 & ROA & received & $\begin{array}{l}\text { Financial Target Proxy } \\
\text { (ROA) has an influence on } \\
\text { the tendency of financial } \\
\text { statement fraud. }\end{array}$ \\
\hline & & ACHANGE & rejected & $\begin{array}{l}\text { Financial Stability Proxy } \\
\text { (ACHANGE) has no } \\
\text { influence on the tendency } \\
\text { of financial statement } \\
\text { fraud. }\end{array}$ \\
\hline & & LEVERAGE & Rejected & $\begin{array}{l}\text { The External Pressure } \\
\text { Proxy (LEVERAGE) has } \\
\text { no influence on the }\end{array}$ \\
\hline
\end{tabular}


AMELIA OKTRIVINA SIREGAR ${ }^{1}$, M. ADAM PRAYOGA ${ }^{2}$, EKA SUDARMAJI $/$ Fraud of Financial Statements in Diamond Theory's Perspective: Empirical Study of Transportation Sub Sector Companies in The Indonesia Stock Exchange

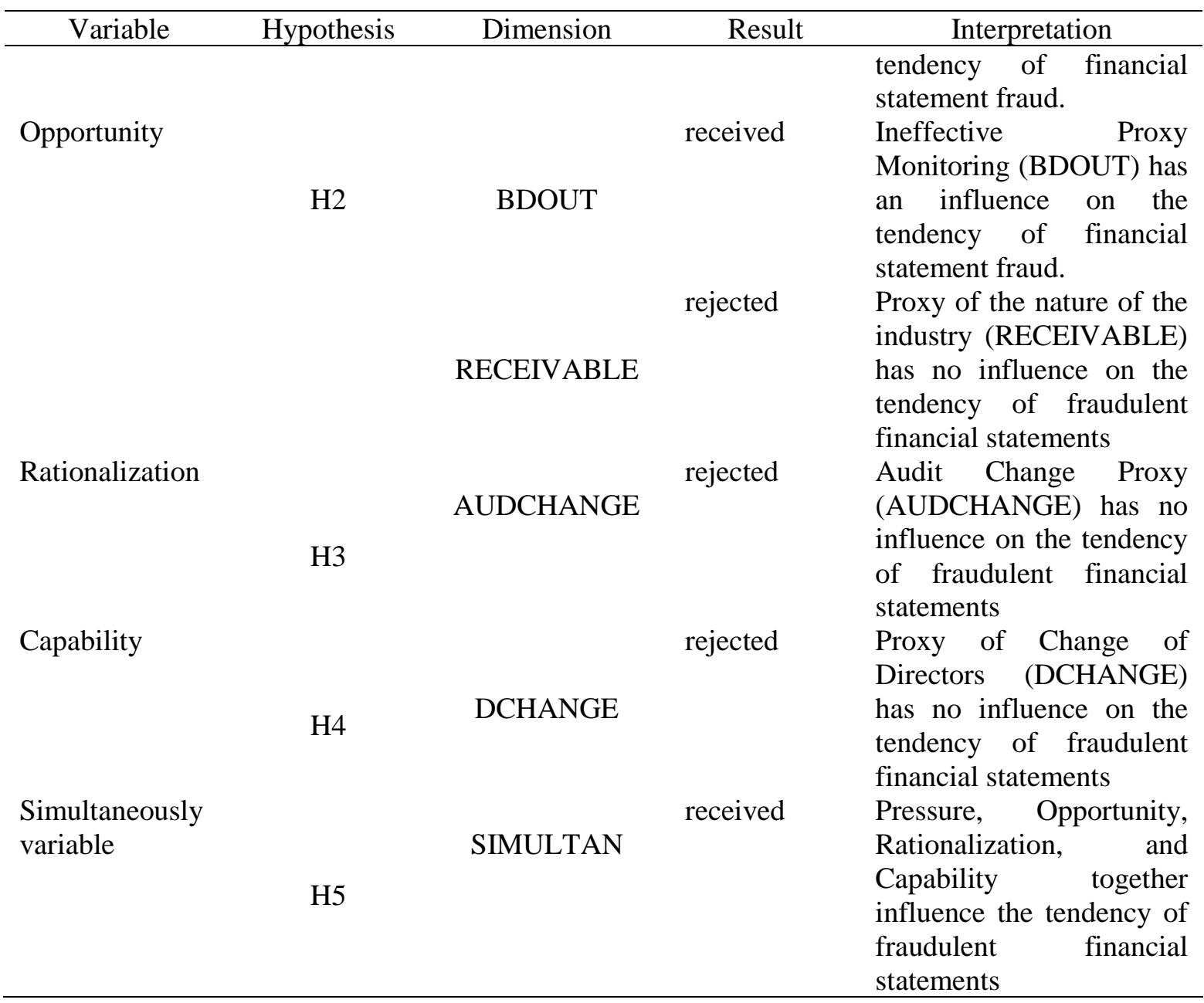

\section{CONCLUSION}

This study aims to determine the effect of pressures (financial stability, financial targets and external pressures), opportunities (industrial nature and ineffectiveness of supervision), rationalization (auditor changes), and capabilities (changes in directors) to the tendency of financial statement fraud. Based on the results of data analysis and discussion, the results of this study can be concluded as follows (1) Pressure variables in this study are proxy with financial targets, financial stability and external pressures. There is a difference in the results of each pressure variable proxy. The pressure variable with the financial target proxy affects the tendency of financial statement fraud, while the financial stability proxy does not affect the tendency of financial statement fraud. (2) The opportunity variable in this study is proxy by the nature of the industry and the ineffectiveness of supervision. Between the two proxies there are two different results. The opportunity variable with the proxy for supervision ineffectiveness affects the tendency of financial statement fraud, while the proxy of the nature of the industry does not affect the tendency of financial statement fraud. (3) The rationalization variable which is proxied by auditor changes does not affect the tendency of financial statement fraud. This shows that the auditor changes proxy as a dimension of the rationalization variable so that the rationalization variable does not affect the tendency of financial statements. (4) Capability variable which is proxied by changes in directors does not affect the tendency of financial statement fraud. This shows that the proxy for changes in directors as a dimension of the capability variable so that the capability variable does not 
affect the tendency of financial statements. (5) Variables of pressure, opportunity, rationalization and capability simultaneously influence the tendency of financial statement fraud.

It can be concluded that through this research the factors in the diamond fraud model, namely pressure, opportunity, rationalization and capability, are allegedly still unable to prove their effect on the tendency of financial statement fraud. Due to differences in the characteristics of each company so that fraud is difficult to detect. As for the results of the study, the tendency of financial statement fraud may occur due to other factors that have not been examined in this study.

\section{REFERENCES}

Albercht, W.S., Albercht, C. O., Albercht, C. C., \& Zimbelman, M. F. (2010). Fraud Examination (Fourthed). Mason: South-Western.

Association of Certified Fraud Examiner. (2014). Report to The Nation On Occupational Fraud and Abuse. ACF. Retrieved November 20,2014, from www.acfe.com

Beasley, M. (1996). An Empirical Analysis of the Relation Between the Board of director Composition and Financial Statement Fraud. The Accounting Review, 71(4), 443-465.

Brennan, N., \& McGrath, M. (2007). Financial Statement Fraud: Some Lessons from US and European Case Studies. Australian Accounting Review. 49-61.

Cressey, D. R. (1953). Other People's Money. Montclair, NJ: Patterson Smith, pp.1-300.

Dechow, P., Sloan, R., \& Sweeny, A. (1996). Causes and Consequences of Earnings Manipulation: An Analysis of Firms Subject to Enforcement actions by the SEC. Contemporary Accounting Research, 13(1), 1-36.

Indonesian Institute of Certified Public Accountants. (2010). Auditing Standard Statement No, 70: Consideration of Fraud in an Audit of Financial Statements. Jakarta: Indonesian Institute of Certified Public Accountants.

Lou, Y. L., \& Wang, M.L. (2009). Fraud Risk Of The Fraud Triangle Assessing the Likelihood of Fraudulent Reporting. Journal of Business and Economics Research. Vol. 7 2,62-66.

Nguyen, K. (2008). Financial Statement Fraud: Method, Cases and Detection. www.dissertation.com

Persons, O.D. (1995). Using Financial Statement Data To Identity Factors Associated With Fraudulent Financial Reporting. Journal of Applied Business \& Economic Research (JBER)., 7(2).

Skousen, C., Smith, K. R., \& Wright, C. J. (2008). Detecting and Predicting Financial Statement Fraud: The Effectiveness Of The Fraud Triangle and SAS No. 99

Soselisa, R., \& Mukhlasin. (2008). The Influence of Organizational Culture, Management, Strategic, Financial, Financial and Auditor Factors on the Tendency of Accounting Fraud: A Study on Indonesian Public Companies: Study on Indonesian Public Companies. Simposium Nasional Akuntansi XI, 1-33.

Summers, S, L., \& Sweeeney. J.T. (1998). Fraud Misstated Financial Statement and Insider trading: an Empirical analysis. Accounting Review. 131-146. 
AMELIA OKTRIVINA SIREGAR ${ }^{1}$, M. ADAM PRAYOGA ${ }^{2}$, EKA SUDARMAJI $/$ Fraud of Financial Statements in Diamond Theory's Perspective: Empirical Study of Transportation Sub Sector Companies in The Indonesia Stock Exchange

Tuankotta, Theodorus M. (2013). Detecting On Manipulated Financial Statement. Jakarta: Salemba Empat.

Wolfe, David T. Dana R. Hermanson. 2004. The Fraud Diamond: Considering The Four Element of Fraud. CPA Journal. 74.12: 38-42. The Fraud Diamond: Considering The Four Elements of Fraud. The New York State Society of CPAs. 